\title{
Public Debt and External Reserve: The Nigerian Experience (1981-2013)
}

\author{
Victoria Senibi, ${ }^{1}$ Emmanuel Oduntan, ${ }^{1}$ Obinna Uzoma, ${ }^{1}$ \\ Esther Senibi, ${ }^{1}$ and Akinde Oluwaseun ${ }^{2}$ \\ ${ }^{1}$ Covenant University, Ota, Nigeria \\ ${ }^{2}$ Federal University of Ilorin, Kwara State, Nigeria \\ Correspondence should be addressed to Victoria Senibi; twinexworld@gmail.com
}

Received 9 July 2016; Revised 22 August 2016; Accepted 30 August 2016

Academic Editor: Donald Lien

Copyright (C) 2016 Victoria Senibi et al. This is an open access article distributed under the Creative Commons Attribution License, which permits unrestricted use, distribution, and reproduction in any medium, provided the original work is properly cited.

\begin{abstract}
Nigeria is confronted with the issue of limited capital and has to resort to foreign debt in order to augment domestic savings, balance of payment deficits, and shortfall in revenue which induce continuous raise in the debt stock at an alarming rate. In the light of this, this study assesses the impact of public debt on external reserve in Nigeria. The objectives of this study include the assessment of the trends and relationship between public debt and external reserve in Nigeria, using the Johansen cointegration and FMOLS technique on the secondary data from 1981 to 2013. The result revealed that public debt has a positive and significant effect on external reserve stock in the long run suggesting that the nation's debt crisis can be attributed to both exogenous and endogenous factors such as the nature of the economy, economic policies, high dependence on oil, and swindling foreign exchange receipt. This study recommends that the federal government should employ more superior method to negotiate for fixed interest payment and varying amortization schemes, as well as seek multiyear rescheduling rather than year by year basis.
\end{abstract}

\section{Introduction}

Debt has no precisely fixed meaning but may be regarded essentially as that which a person or group of people legally owes another or an obligation that is enforceable by legal action to make payment for money owed to another [1]. Technically, a debt is the disbursement of funds made available to a needy entity (or nation) by a wealthy entity or institution, for development and consumption purposes on certain terms of repayment. Thus, when a government borrows, the debt is noted as public debt, which can be incurred from domestic and international financial markets. When the debt is obtained to enable investment in some sort of assets or infrastructure, it is said to be reproductive, which consists of funds borrowed to acquire factories, electricity refineries, and so forth. However, borrowings to finance wars and recurrent expenditures are called dead-weight debts. Furthermore, government borrowing within its boundaries is referred to as domestic debt, which is usually in the form of treasury bills and bonds, while that which is sourced externally from other nations or financial institutions is categorized as foreign or external debt. External debt refers to unpaid portion of foreign resources acquired from developmental purposes and balance of payment support, which are not repaid as they fall due. According to Ajibola et al. [2], external debt is debt owed by a country to other countries or institutions abroad.

On the other hand, external reserves consist of official public sector foreign assets that are readily available to and controlled by the monetary authorities, for direct financing and regulating of payment imbalances through intervention in the exchange markets [3].

Essentially, Obaseki [4] asserted that the effect of public debt on external reserves cannot be overemphasized since, basically, external debts have to be settled in foreign currency. Therefore, the stocks of reserves become a significant source of financing external imbalances; other uses of external reserves include foreign exchange market intervention so as to guide against unforeseen volatility. Although public debt has been seen as one of the ways in which developing countries can complement their low capital stock given their 
high marginal returns on capital, in Nigeria, the public debts have not yielded its desired result due to corruption and fiscal indiscipline. This resulted in the nonsustainability of the country's public debt and depletion of external reserve by government to finance persistent deficit budget which further compound the level of jobless economic growth in the country. In fact, some economists argue that foreign exchange reserves are useless and unutilized, while others argue that reserve holding is necessary to help smooth balance of payments imbalances $[5,6]$.

Moreover, most of the previous studies conducted on external reserves were merely carried out on reserve accumulation and utilization, the demand for international reserves, the impact of reserve holding, implications for investment, inflation, and so on, without assessing the plausible interplay between public debt and external reserve of Nigeria. Thus, the role of public debt as a determinant of external reserve has been underemphasized; this study is aimed at filling the gap in this area.

Therefore, the main objectives of this paper are to examine the trends and relationship between public debt and external reserves in Nigeria as well as the statistical interactions between them.

\section{Literature Review}

Rollover risk faced by the government in an economy is a major reason for the theory of optimum reserves. This elementary model spreads to a dynamic structure to provide a theory for the rise in external reserves and the pattern of abrupt stops in developing economies as pointed by Hur and Kondo [7]. It posits that while short-term reserves, shortterm liquidation, and the interest rate are functions of the aggregate liquidity shock, the rollover policy is a function of both the aggregate state and the individual liquidity shock of an investor. A debt contract is resource feasible. In other words, initial reserves and invested capital cannot exceed the loan amount; and interim reserves and interim payments cannot exceed initial reserves and interim output. Obviously, the main friction here is that the government cannot lend the interim against the future output from the initial investment. Hence, liquidation and reserves are the only resources available to make interim payments.

Similarly, final output and residual reserves are the only resources available to make final payments. The model suggests a condition which requires that the interim rollover policy is to roll over the loan if and only if rolling over yields a higher payment than calling the loan in the interim.

Furthermore, several studies have been conducted on both external reserve and public debt but there is a dearth of studies critically assessing the link between the two despite their huge importance. Akpan and Ala [8] examined the causality between external reserves, economic growth, import, money supply, and public debt servicing in Nigeria from 1980 to 2014 using the Granger Causality, Johansen test, and the Vector Error Correction Model (VECM) techniques of estimation. The study found out that economic growth and imports had a positive and negative relationship with external reserves, respectively, both in the short and in the long run while public debt had a positive and significant relationship with external reserve in the short run but negative in the long run. Also, Izedonmi and Ilaboya [9] assessed the public debt-growth dynamics in Nigeria form 1980 to 2010 using the cointegration and error correction mechanism. They found that there exists a negative and significant relationship between public debt burden and economic growth in Nigeria. Abdullateef and Waheed [10] investigated the effect of variations in external reserve of Nigeria's positions on home investment, inflation, and exchange rate; employing simple Ordinary Least Square (OLS) and Vector Error Correction (VEC) techniques indicated that variations in external reserves primarily stimulate foreign direct investment (FDI) and exchange rates although no effect was established between domestic investment and inflation rates.

Alfaro and Kanczuk [11] emphasized that both reserves and debt were denominated in foreign currency but are not perfect substitutes (as reserves could be used even when the country has defaulted). Subsequently regulating the model for realistic parameter values, the study established that reserve accumulation did not play a quantitatively vital role by means of even consumption. (Instabilities of 75 to 100 times the yardstick regulation and extremely persistent sovereigns were required for the equilibrium quantity of reserves to be positive.) Equally for realistic parameter values reserve accumulation did not increase debt sustainability. For this study debt is denominated in local currency, and reserve accumulation has a significant effect on consumption level via valuation effects; as a result, reserve accumulation increases debt sustainability.

Zhou [12] examined the correlation between the form of fiscal policy and the demand for international reserves in emerging countries, how this relationship is related with political risk and conditional access to global capital markets. The study employed Two Stage Least Squares (2SLS) to discover developing countries with low political risk, counter-cyclical (procyclical) fiscal policies associated with higher (lower) international reserve holdings in economic downturns. The relationship is stronger in countries with low political risk that depend heavily on external financing; emerging countries with high political risk show that the link between reserves holdings and fiscal policy pattern is not clear-cut. While Yin-Wong and Hiro [13] carried out a widespread cross-country empirical analysis of the determining factors of international reserves between the periods of 1975 to 2004, they used data from more than 100 economies, including both developed and developing economies to study the impact on international reserves holding three groups factors, namely, traditional macro variables, financial variables, and institutional variables. They laid emphasis on the interaction between these variables and their varying functions in influencing international reserve using a large sample of economies; they compared the behavior of crisis-inflicted and non-crisis-inflicted economies evaluating if international reserves of these economies behave differently before and after crises. Using the estimated results to compare and contrast the patterns of demand for international reserves for both the developed and developing economies, the estimated results indicate that, for developed and developing 
economies, the explanatory power of each determining factor varies across diverse time periods. The structures of each significant determining factor within the three groups of the explanatory variables showed substantial variations across subsample periods and country groups; also the behavior of crisis-inflicted economies can be recognized only in selected cases but not uniformly. The outcomes of this study proposed that, relative to both developing and developed countries, the economy tends to embrace lower level of international reserves ceteris paribus.

Guangqing [14] assessed the anticipated stock of reserves for China showing deviations in the actual stock from the desired level that triggers a process of adjustment and also the speed of adjustment was relatively high in China. The paper showed that all the variables excluding the debt rate had significant values and also revealed specific features involved in China's reserve adjustment depiction.

Conclusively, these empirical reviews revealed different variables that may affect external reserve holdings of any nation but most of them did not capture the influence of public debt on external reserve holdings in any economy.

\section{Stylized Facts}

Trends of External Reserve and Public Debt of Nigeria. Trends of External Reserve and Public Debt of Nigeria presented in Figure 1 revealed that the external reserve of Nigeria oscillated below US $\$ 11$ billion from 1981 to 2002 but rose sharply from about US $\$ 7.5$ billion in 2003 to US $\$ 51.3$ billion by the end of 2007. This rise could be explained by the three-time increase in the spot price of crude oil (which is the main source of Nigerian external reserve) from about US $\$ 31$ per barrel in 2003 to about US $\$ 95$ per barrel by the end of 2007 [15]. However, the public debt of the country was way below US $\$ 4$ billion from 1981 to 1999 and kept growing to about US $\$ 8.1$ billion in 2007 which was largely driven by the continuous rise in domestic debt by the democratic government in Nigeria even with the debt forgiveness in 2005 [16]. The growth of government bureaucracy permitted by the oil boom, as well as the establishment of public corporations that had to be maintained even after government revenue (mainly from oil) had declined made government expenditures to remain high with persistence growth in the nation's debt profile.

Also, the external reserve fell from about US $\$ 53$ billion in 2008 to about US $\$ 32$ billion in 2010 even when the crude oil price was over US $\$ 80$ per barrel during this period [16] while debt burden was rising due largely to rolling over of deficient budget being operated by the government. Both public debt and external reserve keep rising but the debt burden rose faster than the external reserve. In fact, [17] asserted the idea that the current account deficit could be connected to the fiscal situation and that having internal and external deficits at the same time may be risky for the economy. This could raise domestic credit and have a lasting negative impact on the current account resulting in increase in public debt burden of any economy particularly the developing economy.

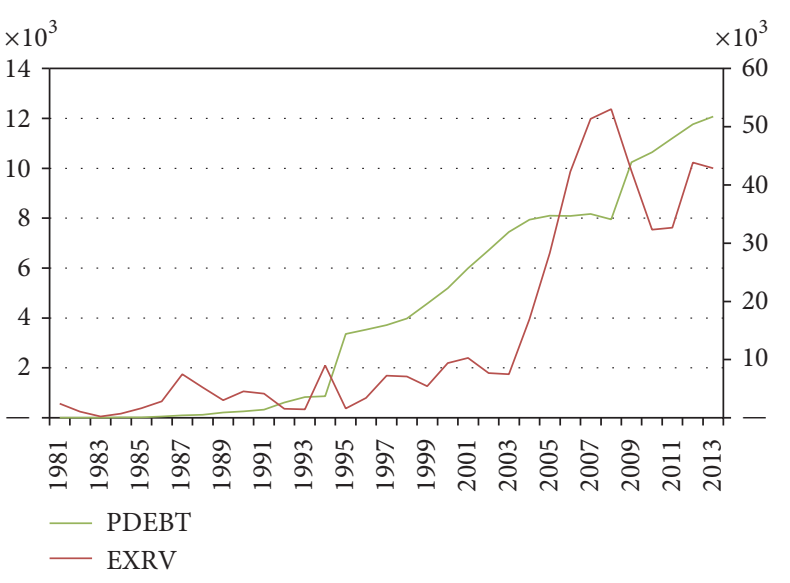

Figure 1: Trends of External Reserve and Public Debt of Nigeria (in US\$ million). Source: CBN Annual Statistical Bulletin [16]; authors compilation using E-views 9.0.

\section{Methodology}

This study employed econometric technique to assess the interplay between external reserve and public debt among other associated variables. The descriptive method consists of trend graph as shown in Figure 1 to evaluate the pattern of public debt and external reserve thus explaining the behavior of both variables from 1981 to 2013. This scope provides a long period dynamic of variables and their effect on the performance of the Nigeria foreign reserve. The Structural Adjustment Program (SAP) was adopted in 1986, as an alternative framework for addressing the weaknesses and ineffectiveness of previous development planning and revenue shortfall resulting in unchecked external borrowing. The econometric methods adopted include Augmented Dickey Fuller Stationary test, Johansen cointegration, and Fully Modified Ordinary Least Square (FMOLS).

4.1. Model Specification. The theoretical framework employed is the theory of optimal reserves allocation which exists in an environment where governments face rollover risk in the form of debt rescheduling. This basic model extends to a dynamic framework to provide a theory for the increase in reserves and the pattern of sudden stops in emerging. It posits that while interim reserves, interim liquidation, and the interest rate are functions of the aggregate liquidity shock, the rollover policy is a function of both the aggregate state and the individual liquidity shock of an investor. A debt contract is resource feasible. In other words, initial reserves and invested capital cannot exceed the loan amount; and interim reserves and interim payments cannot exceed initial reserves and interim output. Obviously, the main friction here is that the government cannot lend the interim against the future output from the initial investment. Hence, liquidation and reserves are the only resources available to make interim payments. Similarly, final output and residual reserves are the only resources available to make final payments. The model suggests a condition which requires that the interim rollover 
TABLE 1: Summary statistics of variables in the model.

\begin{tabular}{|c|c|c|c|c|}
\hline Variables & EXTR & PDEBT & M2 & NEXCR \\
\hline Mean & 14874.41 & 4368.385 & 2788412 & 65.46242 \\
\hline Median & 7222.22 & 3716.99 & 413280.1 & 81.3 \\
\hline Maximum & 53000.36 & 12075.41 & 15158622 & 113.2 \\
\hline Minimum & 224.4 & 8.25 & 14471.17 & 0.74 \\
\hline Std. deviation & 17114.58 & 4191.516 & 4510011 & 42.9984 \\
\hline Skewness & 1.097089 & 0.401345 & 1.637805 & -0.4275 \\
\hline Kurtosis & 2.609808 & 1.738512 & 4.258938 & 1.4412 \\
\hline Jarque-Bera & 6.829171 & 3.074036 & 16.93251 & 4.34601 \\
\hline Probability & 0.03289 & 0.215021 & 0.00021 & 0.11384 \\
\hline Sum & 490855.6 & 144156.7 & 92017589 & 2160.26 \\
\hline Sum sq. dev. & $9.37 E+09$ & $5.62 E+08$ & $6.51 E+14$ & 59163.6 \\
\hline Observation & 33 & 33 & 33 & 33 \\
\hline
\end{tabular}

Source: author's computation using E-views 9.0.

policy is to roll over the loan if and only if rolling over yields a higher payment than calling the loan in the interim.

In an attempt to assess the relationship between government total borrowing and external reserves, this study takes a clue from the theory of optimal reserves allocation in analyzing this relationship; the first is external reserves usually denominated in foreign currencies and kept in banks in developed economies. The second is the borrowing by the government from both domestic and external sources summed up as public debt. The model formulation is specified as follows:

$$
\mathrm{EXTRV}_{t}=F\left(\mathrm{PDEBT}_{t}, \mathrm{M}_{t}, \mathrm{NEXCR}_{t}\right),
$$

where EXTRV stand for external reserves, PDEBT stand for public debt, M2 stand for broad money supply, and NEXCR stand for nominal effective exchange rate.

This study assumes a nonlinear model structured which in its explicit form becomes

$$
\operatorname{EXTRV}_{t}=A \cdot \operatorname{PDEBT}_{t}^{\beta 1} \cdot \mathrm{M}_{t}^{\beta 2} \cdot \operatorname{NEXCR}_{t}^{\beta 3} \cdot e_{t} .
$$

Taking the double log form of this model becomes

$$
\begin{aligned}
\log \mathrm{EXTRV}_{t}= & \log \beta_{0}+\beta_{1} \log \mathrm{PDEBT}_{t}+\beta_{2} \log \mathrm{M} 2 \\
& +\beta_{3} \log \mathrm{NEXCR}_{t}+\log U_{t} .
\end{aligned}
$$

$\beta_{0}$ is the intercept while $\beta_{1}, \beta_{2}$, and $\beta_{3}$ are the parameters; $t=1981$ to $2013 ; U_{t}=$ error term

$$
\begin{aligned}
& \beta_{1}<0, \\
& \beta_{2} \lessgtr 0, \\
& \beta_{3}<0 .
\end{aligned}
$$

From the above model the variables used are four: EXTRV (external reserve), PDEBT (public debt or $\beta_{1}$ ), M2 (broad money supply or $\beta_{2}$ ), and NEXCR (nominal exchange rate or $\beta_{3}$ ). The contribution of external reserve to Nigeria debts profile is explained below
4.2. Estimation Technique. The test conducted is used to derive solutions from the analysis of data to enable the verification of both theoretical and statistical validity of our coefficients. This study employed Johansen cointegration estimation technique to determine the existing long run relationship between external reserve and public debt in Nigeria using E-views 9 Statistical Package.

4.3. Data Sources and Measurements. Secondary data for this study were sourced from Central Bank of Nigeria Statistical Bulletin 2013 published by CBN [16]. Both external reserve and public debt were measured in US dollar while broad money supply and nominal effective exchange rate were measured in naira. However, in order to assess their relationship without the complexity of various measurement; all the variables were logged and interpreted with respect to their elasticity.

\section{Interpretation and Discussion of Results}

This study deals with the presentation of data, analysis of data, and interpretation of findings from the model put forward as well as testing of the research hypothesis. The parameter estimates were subject to various economic and econometric tests. The logarithms of the variables were obtained to bring the time-series data on the variables to the same base.

5.1. Summary Statistics. These statistics are used to describe the main features of the data set which include measures of central tendency (mean, median, and mode); measures of variability (standard deviation, variance); the minimum and maximum values of variables (kurtosis and skewness) providing summary of samples and observations which forms the basis for the description of the data set.

Table 1 shows the statistical analysis of the variables EXTRV, PDEBT, M2, and NEXCR with their respective mean (14874.41, 4368.385, 2788412, and 65.46242) which is the sum of all the values in the data group divided by the total number of the values and their respective standard deviation (17114.58, 
TABLE 2: Correlation matrix for variables in the model.

\begin{tabular}{lcccc}
\hline Variables & EXTR & PDEBT & M2 & NEXCR \\
\hline EXTR & 1.000000 & 0.831559 & 0.836028 & 0.460382 \\
PDEBT & 0.831559 & 1.000000 & 0.851745 & 0.527093 \\
M2 & 0.836028 & 0.851745 & 1.000000 & 0.437655 \\
NEXR & 0.460382 & 0.527093 & 0.437655 & 1.000000 \\
\hline
\end{tabular}

Source: author's computation using E-views result.

TABLE 3: ADF unit root test and order of integration.

\begin{tabular}{lcccc}
\hline Variables & ADF $t$-Statistic Value & $5 \%$ critical value & Remark & Order of integration \\
\hline$d($ lextrv $)$ & -6.8100 & -2.9639 & Stationary & $\mathrm{I}(1)$ \\
Lextrv & -1.2971 & -2.9571 & Nonstationary & $\mathrm{I}(0)$ \\
$d(\operatorname{lm} 2)$ & -2.9998 & -2.9604 & Stationary & $\mathrm{I}(1)$ \\
Lm2 & -0.4456 & -2.9604 & Nonstationary & $\mathrm{I}(0)$ \\
$d($ lpdebt $)$ & -4.6959 & -2.9604 & Stationary & $\mathrm{I}(1)$ \\
Lpdebt & -2.8333 & -2.95711 & Nonstationary & $\mathrm{I}(0)$ \\
$d($ lnexcr $)$ & -4.0526 & -2.9604 & Stationary & $\mathrm{I}(1)$ \\
Lnexcr & -1.1846 & -2.95711 & Nonstationary & $\mathrm{I}(0)$ \\
\hline
\end{tabular}

Source: author's computation from E-views (2016).

4191.516, 4510011, and 42.9984) which is the positive square root of the variance.

Skewness shows the degree of asymmetry of the distribution and this could be negatively or positively skewed, and kurtosis measures the degree to which the frequency distribution is focused about its mean or the peakedness of the distribution and it could be mesokurtic (when the kurtosis coefficient is $=0$ ), platykurtic (when the kurtosis coefficient is $<0$ ), and leptokurtic (when the kurtosis coefficient is $>0$ ). Looking at the skewness, all variables were all positively skewed and examining the kurtosis; all variables had their entire kurtosis coefficient $>0$ which shows that they are leptokurtic.

5.2. Correlation Matrix. The correlation matrix determines the degree of relationship existing between two random variables of a data set involving dependence and thus computes the correlation coefficients of row $_{i}$ and column matrix in $_{j}$ which the diagonal element must be 1 .

Correlation coefficient matrix determine the strength and direction of linear relationship between two variables that lines between -1 and +1 ; the closer the correlation coefficient is to $-1 /+1$ a perfect linear and stronger relationship exists between the variables. From Table 2, the correlation coefficients of the various variables (EXTRV, PDEBT, M2, and NEXCR) were presented and this shows that there exist positive correlation coefficients among all variables.

5.3. Stationarity Test. The results of the Augmented Dickey Fuller (ADF) unit root test show that all the variables are stationary at first difference. Table 3 shows the results of the stationarity test in summary and the order of integration using ADF test.

A variable is stationary when the absolute value of ADF $t$ Statistic Value is greater than the absolute value of $5 \%$ critical value. Since all the variables were nonstationary at level, they were first differenced once, and the other variables become stationary. This implies that all the variables are order I(1) series. Since all the variables are order 1 series then Johansen cointegration can be conducted while Ordinary Least Square cannot be conducted because the assumption of constant variance is violated.

5.4. Johansen Cointegration Test. The cointegration test establishes whether a long run equilibrium relationship exists among the variables of interest.

\section{Test of Cointegration Hypotheses}

$$
\begin{aligned}
& \left(H_{0}\right) \gamma=0 \text { (no cointegrating equation). } \\
& \left(H_{1}\right) \gamma \neq 0 \text { (cointegrating equations). }
\end{aligned}
$$

Table 4 presents the Unrestricted Cointegration Rank Test (Trace); the trace statistic (48.3075) is greater than $5 \%$ critical value (47.8561); hence, reject the null hypothesis of no cointegrating equation and accept the alternate hypothesis of cointegrating equations. To confirm this, $p$ value of the null hypothesis from the trace table $(0.0453)$ is less than 0.05 . Therefore, reject the null hypothesis and accept alternate hypothesis. But accept the null hypothesis of "at most 1" and conclude that the model consists of one cointegrated equation. Therefore, using the unrestricted cointegrating rank test (trace), there are no cointegrating equations.

Another way to check for the presence of cointegration is the use of Unrestricted Cointegration Rank Test (maximum Eigen value). Here, the Max-Eigen statistic (28.699) is greater than $5 \%$ critical value (27.584). Hence, reject the null hypothesis of no cointegrating equations and accept the alternate hypothesis of the presence of cointegration. Also, the $p$ value of the null hypothesis from the Max-Eigen table (0.0448) is less than 0.05 . Therefore, reject the null hypothesis and accept the alternate hypothesis. But accept null hypothesis 
TABLE 4: Summary of cointegration results.

\begin{tabular}{lccccccc}
\hline Max rank & Eigenvalue & Trace statistics & Prob. & 5\% critical values & Max-Eigen statistic & Prob. & $5 \%$ critical values \\
\hline None $^{*}$ & 0.4871 & 48.30750 & 0.045 & 47.85613 & 28.69996 & 0.0448 & 27.58434 \\
At most 1 & 0.3974 & 27.60754 & 0.0876 & 29.79707 & 15.70159 & 0.2428 & 21.13162 \\
At most 2 & 0.2580 & 11.90595 & 0.1615 & 15.49471 & 9.254710 & 0.2656 & 14.26460 \\
At most 3 & 0.0819 & 2.651243 & 0.1035 & 3.841466 & 2.651243 & 0.1035 & 3.841466 \\
\hline
\end{tabular}

Note that “*” indicates the cointegrating equation; source: author's computation from E-views 9.0.

TABLE 5: FMOLS result.

\begin{tabular}{|c|c|c|c|c|}
\hline Variable & Coefficient & Std. error & $t$-statistic & Prob. \\
\hline LM2 & 0.001597 & 0.000364 & 4.384688 & 0.0001 \\
\hline LNEXCR & 10.95699 & 24.95413 & 0.439085 & 0.6640 \\
\hline LPDEBT & 1.804218 & 0.430598 & 4.190032 & 0.0003 \\
\hline C & 1544.229 & 1623.164 & 0.951370 & 0.3496 \\
\hline$R$-squared & 0.746468 & Mean dependent var & & 15262.94 \\
\hline Adjusted $R$-squared & 0.719304 & SD dependent var & & 17239.94 \\
\hline SE of regression & 9133.848 & Sum squared resid & & $2.34 E+09$ \\
\hline Long run variance & 23394611 & & & \\
\hline
\end{tabular}

Source: author's computation from E-views (2016).

Dependent variable: Lextrv; method: Fully Modified Least Squares (FMOLS); sample (adjusted): 1982-2013; included observations: 32 after adjustments; cointegrating equation determinants: $C$; long run covariance estimate (Bartlett kernel; Andrews bandwidth $=15.4589$ ).

of "at most 1 " and conclude that one cointegrated (see Table 4). Therefore, using the unrestricted cointegrating rank test (Max-Eigen), there is one cointegrating equation.

Therefore, it is concluded that both unrestricted cointegrating rank test (trace) and unrestricted cointegrating rank test (Max-Eigen) confirmed the presence of cointegrating equations. Hence, there is a long run relationship between the dependent variable (Lextrv) and the independent variables (LM2, LNEXCR, and LPDEBT).

5.5. Fully Modified OLS (FMOLS). The FMOLS was employed to evaluate the long run impact of the independent variables on the dependent variable since Johansen cointegration test confirms the presence of long run association of the variables employed. From the FMOLS results in Table 5, the adjusted $R^{2}$ of 0.719 indicates that the independent variables (public debt, nominal exchange rate, and broad money supply) in the model jointly explain 71.9 percent variations in the dependent variable (external reserve) whereas other variables not captured in this model explained 28.1 percent changes in the dependent variable.

The probability value of the individual explanatory variable reveals that all the explanatory variables (broad money supply and public debt) are statistically significant at 5 percent significant level except normal exchange rate to US dollar which is insignificant. Specifically, 1 percent raise in public debt could induce 1.80 percent increase in external debt in the long run. This implies that foreign currency debt issuance can induce increase in external reserve but it can bring serious difficulties in evaluating reserve adequacy since increasing debt could raise the uncertainty in external reserve dynamics.

Also, 1 percent increase in broad money supply could induce 0.0016 percent rise external reserve in the long run.
This suggests that the influence of broad money supply is inconsequential since broad money supply which is an indicator of resident capital flight does not Granger-cause change in external reserve [18].

\section{Conclusion and Policy Recommendations}

Nigeria public debt and broad money supply exert a long run positive and significant effect on external reserve while nominal exchange rate was insignificantly related to external reserve. This study shows the extent to which the Nigerian's outstanding public debt reflects on the economy's external reserve particularly from the time of the outbreak of oil crisis in 1981. Besides rapid accumulation of trade arrears from 1982 the issue of debt resulted from fall in crude oil prices, collapse in commodity prices, and the protracted softening of the World market since 1981 causing reduction in external exchange earnings and balance of payment. Also, the debt crisis of Nigeria constitutes exogenous and endogenous such as the nature of the economy, economic policies, high depending on oil, and swindling of foreign exchange receipt. Thus, from the key findings of the study, the analysis reveals that the economic variables used have high influence on the external reserve from the model specified.

Based on key findings of this study, the study recommends that the Nigeria Debt Management Office should lay down healthy guideline for public loans, outlining the purpose, time frame, moratorium necessities and commitments, negotiation fees, and so forth as well as the conditions in which the administration can admit and guarantee loans particularly for external debt. Also, new and superior technique to assign fixed interest payment and unstable amortization systems must be employed. Funds from external debt must 
be channeled towards projects with high returns devoid of misappropriation in the long run; economic policies should also be channeled towards export promotion and import substitution as this would increase the level of productivity and economic activities thereby resulting in an improvement in external reserve, a favorable balance of payment and increase in foreign exchange earnings.

\section{Competing Interests}

The authors Victoria Senibi, Emmanuel Oduntan, Obinna Uzoma, Esther Senibi, and Akinde Oluwaseun declare that there are no competing interests regarding the publication of this article.

\section{References}

[1] A. A. Adepoju, A. S. Salau, and A. E. Obayelu, "The effects of external debt management on sustainable Economic growth and development: lessons from Nigeria," Munich Personal RePEC Achieve (MPRA) 2147, 2007.

[2] I. O. Ajibola, U. S. Udoette, B. S. Omotosho, and Rabia, "Nonlinear adjustments between exchange rates and external reserves in Nigeria: a threshold cointegration analysis," $C B N$ Journal of Applied Statistics, vol. 6, no. 1, 2015.

[3] IMF, "Are foreign reserves in Asia too high?" in World Economic Outlook, H. Edison, Ed., chapter 2, International Monetary Fund, Washington, DC, USA, 2003.

[4] P. J. Obaseki, "Foreign exchange management in nigeria. past, present and future," CBN Economic and Financial Review, vol. 39, no. 1, pp. 12-223, 2007.

[5] A. R. Kemal, "Optimal level of reserves in developing economies with special reference to Pakistan," Public Policy Papers 1, Pakistan Institute of Development Economics, Islamabad, Pakistan, 2002.

[6] Friedman, "The case for flexible exchange rates," in Essays in Positive Economics, pp. 157-203, University of Chicago Press, Chicago, Ill, USA, 1953.

[7] Hur \& Kondo, A Theory of Sudden Stops, Foreign Reserves, and Rollover Risk in Emerging Economies, Federal Reserve Bank of Minneapolis, 2011.

[8] E. Akpan and T. Ala, "Causality between external reserves, economic growth,import, money supply and public debt servicing: evidence from Nigeria," Research Journal of Finance and Accounting, vol. 7, no. 2, pp. 1-7, 2016.

[9] F. Izedonmi and O. Ilaboya, "Public debt-growth dynamics: the Nigerian experience," Journal of Research in National Development, vol. 10, no. 3, pp. 1-10, 2012.

[10] U. Abdullateef and I. Waheed, "External reserve holdings in Nigeria: implications for investment, inflation and exchange rate," Journal of Economics and International Finance, vol. 2, no. 9, pp. 183-189, 2010.

[11] L. Alfaro and F. Kanczuk, "Sovereign debt as a contingent claim: a quantitative approach," Journal of International Economics, vol. 65, no. 2, pp. 297-314, 2005.

[12] Y. Zhou, International Reserves and Fiscal Policy in Developing Countries SCCIE Working Paper \#06-18 Santa Cruz Center for International Economics, https://www.econstor.eu/bitstream/ 10419/64123/1/60464065X.pdf.
[13] C. Yin-Wong and I. Hiro, "A cross-country empirical analysis of international reserves," Economic Journal, vol. 99, pp. 307-314, 2006.

[14] X. Guangqing, "The scale, demand and dynamic adjustment for China's foreign Exchange reserves," in Proceedings of the 3rd Annual International Conference: Hawaii International Conference on Business, Honolulu, Hawaii, USA, June 2003.

[15] World Bank, World Bank Data Report, World Bank, Washington, DC, USA, 2014, http://data.worldbank.org/country/ nigeria.

[16] Central Bank of Nigeria, Annual Statistical Bulletin, Central Bank of Nigeria, Abuja, Nigeria, 2013.

[17] G. T. Ganchev, "The twin deficit hypothesis: the case of Bulgaria," Financial Theory and Practise, vol. 34, no. 4, pp. 357377, 2010.

[18] O. Olatunji and M. I. Oloye, "Impacts of capital flight on economic growth in Nigeria," International Journal for Innovation Education and Research, vol. 3, no. 8, pp. 10-44, 2015. 


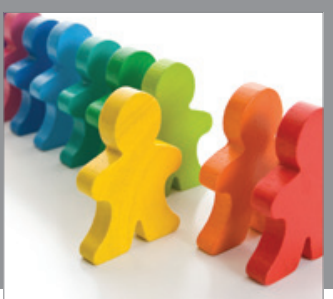

Autism

Research and Treatment
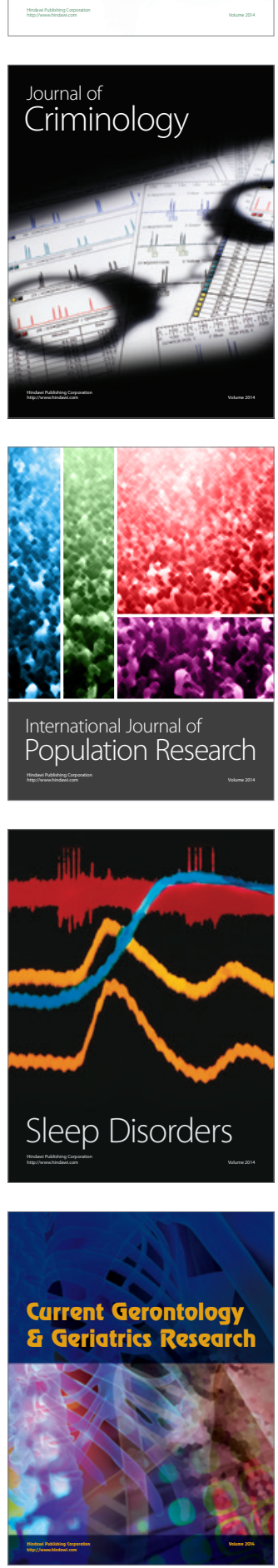

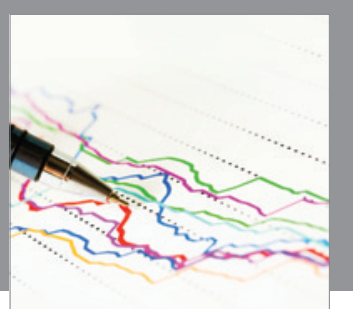

Economics

Research International
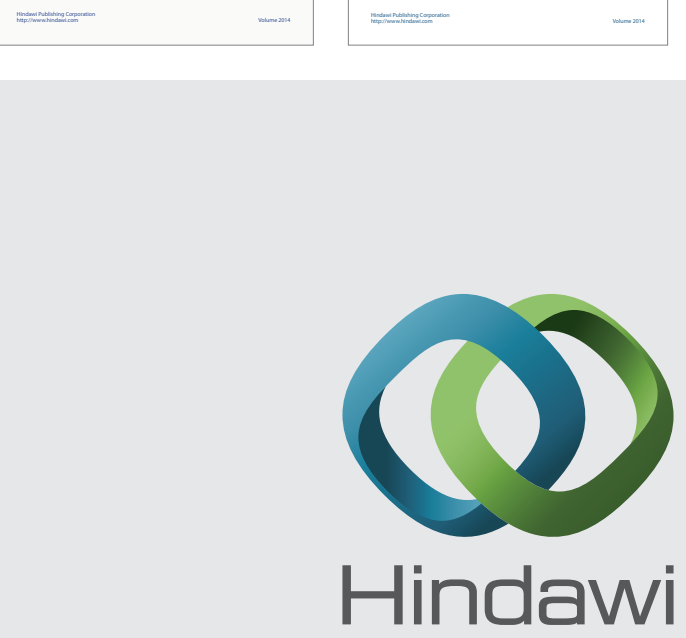

Submit your manuscripts at

http://www.hindawi.com
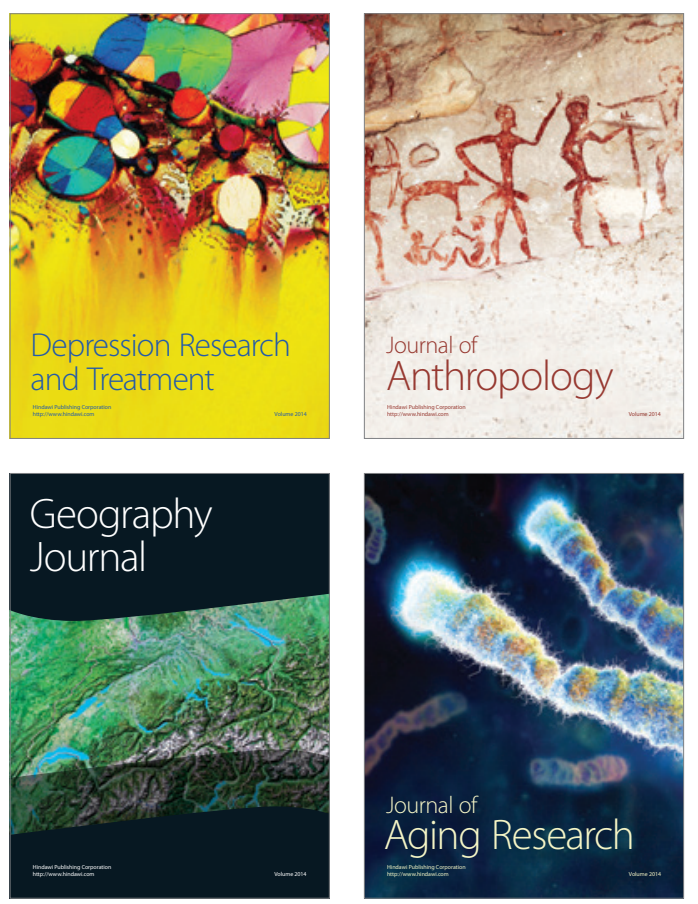
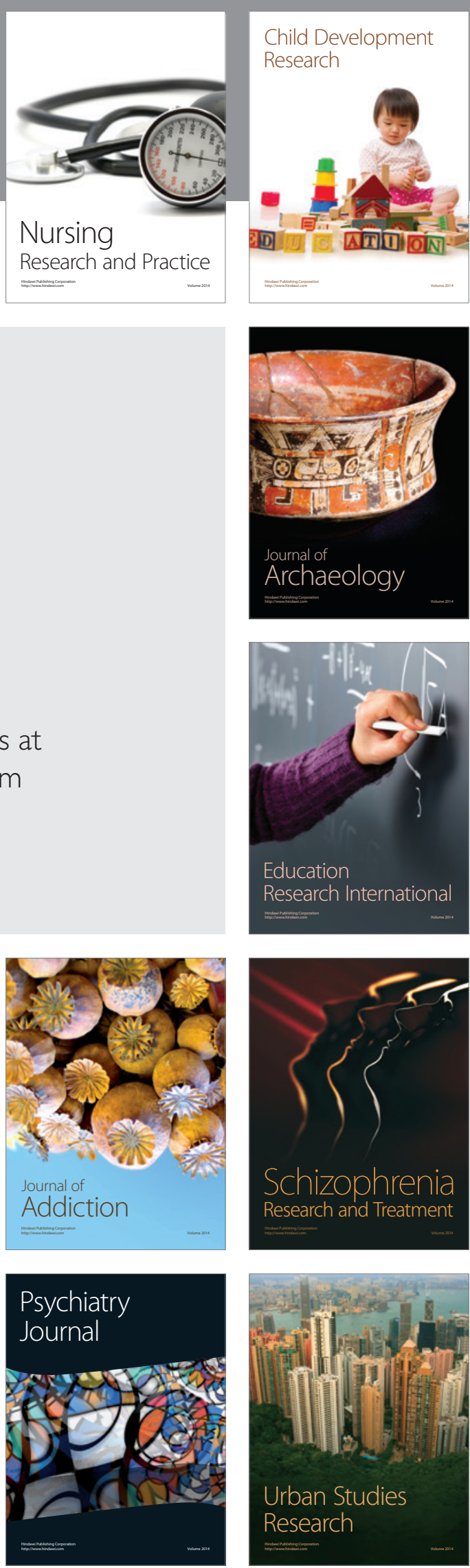